\title{
Kształtowanie wizerunku organizacji pozarządowych ${ }^{1}$
}

\begin{abstract}
Kamila Pilch*
Streszczenie: Jednym z ważniejszych niematerialnych zasobów współczesnych organizacji jest wizerunek. Kreowanie i zarządzanie nim jest istotne z punktu widzenia wszystkich organizacji, w tym również organizacji pozarządowych, konkurujących o wolontariuszy, sponsorów czy sympatyków. Celem artykułu jest przedstawienie technik public relations umożliwiających zarządzanie komunikacją w celu kreowania wizerunku. W opracowaniu przedstawione zostały podstawowe komponenty, z których składa się wizerunek, techniki public relations wykorzystywane w zarządzaniu komunikacją z otoczeniem wewnętrznym i zewnętrznym oraz wyniki dotychczasowych badań wizerunkowych trzeciego sektora. Przeprowadzone analizy wskazują na potrzebę prowadzenia systematycznych działań wspierających kształtowanie wizerunku zarówno trzeciego sektora jako całości, jak i poszczególnych organizacji działających w jego ramach.
\end{abstract}

Słowa kluczowe: wizerunek, kształtowanie wizerunku, organizacje pozarządowe.

\section{Wprowadzenie}

Z roku na rok powstaje coraz większa liczba organizacji pozarządowych. Według danych portalu ngo.pl zarejestrowanych jest obecnie 135000 organizacji, z czego szacuje się, że około $70-75 \%$ z nich prowadzi aktywną działalność ${ }^{2}$. Podmioty funkcjonujące $w$ trzecim sektorze przechodzą proces profesjonalizacji nie tylko pod kątem merytorycznej działalności, ale także w zakresie zarządzania, kierowania organizacją, promocji, kreowania wizerunku i szeroko pojętej współpracy z mediami [Kotnis-Górka, Wysocki, 2011]. W budowaniu przewagi konkurencyjnej ważną rolę odgrywają zasoby niematerialne przedsiębiorstw, w tym przede wszystkim ich wizerunek. Jego

Publikacja została przygotowana w projekcie „Doskonalenie usług w sektorze publicznym: wymiar europejski" nr: 057/ WGAP-KAP/02/2018/S/8057, dofinansowanym z dotacji Ministerstwa Nauki i Szkolnictwa Wyższego dla Wydziału Gospodarki i Administracji Publicznej Uniwersytetu Ekonomicznego w Krakowie na utrzymanie potencjału badawczego.

2 https://fakty.ngo.pl/fakt/liczba-ngo-w-polsce (dostęp: 13.12.2018). umiejętne budowanie wymaga zastosowania technik i narzędzi wypracowanych na gruncie public relations.

Celem artykułu jest przedstawienie narzędzi z zakresu public relations, które mogą być stosowane w budowaniu wizerunku i komunikacji z otoczeniem przez organizacje pozarządowe. Opracowanie składa się z czterech części. W pierwszej z nich zdefiniowany został termin organizacja pozarzq̨dowa oraz specyfika działania tego rodzaju podmiotów, następnie przedstawiono wyniki dotychczasowych badań wizerunkowych organizacji pozarządowych. W kolejnej części omówione zostały główne komponenty i sposoby konceptualizacji pojęcia wizerunek, a następnie wymieniono, za pomocą jakich narzędzi public relations możliwe jest zarządzanie komunikacją

\footnotetext{
* Kamila Pilch

Katedra Administracji Publicznej

Uniwersytet Ekonomiczny w Krakowie

ul. Rakowicka 16, 31-510 Kraków

e-mail: kamila.pilch@uek.krakow.pl
} 
z otoczeniem wewnętrznym i zewnętrznym organizacji.

\section{Organizacje pozarządowe}

Od lat 40. ubiegłego stulecia organizacje przyporządkowuje się do trzech głównych sektorów społeczno-gospodarczych [Bogacz-Wojtanowska, 2016]. Pierwszy z nich to sektor publiczny, którego zadaniem jest zaspokajanie potrzeb obywateli zgodnie $z$ istniejącymi regulacjami prawnymi. Drugi sektor tworzą przedsiębiorstwa i utożsamiany jest z biznesem. Trzeci sektor (obywatelski) tworzą formalne i nieformalne inicjatywy oraz organizacje.

Organizacje pozarządowe ${ }^{3}$ definiowane są jako współczesne formy samoorganizacji społecznej, struktury integrujące grupy obywateli, które charakteryzują się względnie dojrzałą tożsamością społeczną, określonym stopniem zorganizowania, prywatnym charakterem inicjatywy, dobrowolnością uczestnictwa, niezależnością i niekomercyjnością a także, na ogół, znacznym udziałem wolontariatu i istotną rolą w kształtowaniu postaw ludzkich [Gliński, 2006]. Podstawowym celem ich funkcjonowania nie jest zysk, a działalność na rzecz wybranego interesu publicznego [Brzuska, Kuklak-Dolata, Nyk, 2017]. Obowiązująca ustawa z dnia 24 kwietnia 2003 r. o działalności pożytku publicznego i o wolontariacie ${ }^{4}$ wyklucza z kategorii organizacji pozarządowych podmioty, które:

- są jednostkami sektora finansów publicznych w rozumieniu ustawy z dnia 27 sierpnia 2009 o finansach publicznych lub są przedsiębiorstwami, instytutami badawczymi, bankami i spółkami prawa handlowego będącymi państwowymi lub samorządowymi osobami prawnymi,

- działają w celu osiągnięcia zysku,

\footnotetext{
W pracy stosowane będą zamiennie terminy: organizacja pozarządowa oraz NGO.

4 Dz.U. 2018 poz. 450, z późn. zm.
}

- są osobami prawnymi lub jednostkami organizacyjnymi nieposiadającymi osobowości prawnej, którym odrębna ustawa przyznaje osobowość prawną.

Trzeci sektor tworzony przez rozmaite podmioty, w tym głównie fundacje i stowarzyszenia, jest ważnym elementem budowy społeczeństwa obywatelskiego. To właśnie aktywność zrzeszania się ludzi w dobrowolnych organizacjach w celu realizacji wspólnych zadań jest - obok korzystania przez społeczeństwo z praw politycznych - wskaźnikiem zaufania społecznego w badaniu Diagnoza Społeczna [Czapiński, Panek, 2015]. Zaufanie społeczne jest z kolei jednym z istotnych elementów budowy społeczeństwa obywatelskiego. Przy tym profil działalności organizacji tworzących trzeci sektor może być różnorodny i jest związany z np. sportem, ekologią, sztuką, zdrowiem, rozwojem lokalnym, rynkiem pracy itd.

W świetle powyższych rozważań szczególnie istotny jest społeczny wizerunek podmiotów tworzących trzeci sektor. NGO są traktowane jako instytucje zaufania społecznego, które identyfikując luki w potrzebach społecznych starają się je wypełnić, często dysponując przy tym publicznymi pieniędzmi. Z tej perspektywy ważnym elementem jest sposób ich postrzegania, nie tylko przez grupy, do których kierują one swoje działania, ale również przez ich pracowników, ogół społeczeństwa oraz media. Społeczny wizerunek trzeciego sektora i podmiotów działających w jego ramach jest jednym z kluczowych elementów decydujących o możliwości pozyskania sympatyków, wolontariuszy, pracowników czy sponsorów.

\section{Wizerunek organizacji pozarządowych w Polsce}

Dla każdej organizacji pierwszym krokiem w budowaniu strategii PR-owych jest zbadanie stanu wyjściowego, w tym identyfikacja, w jaki sposób dany podmiot jest postrzegany przez otoczenie. W przypadku organizacji pozarządowych działających w Polsce ich wizerunek 


\section{Rysunek 1. Zaufanie do organizacji trzeciego sektora}

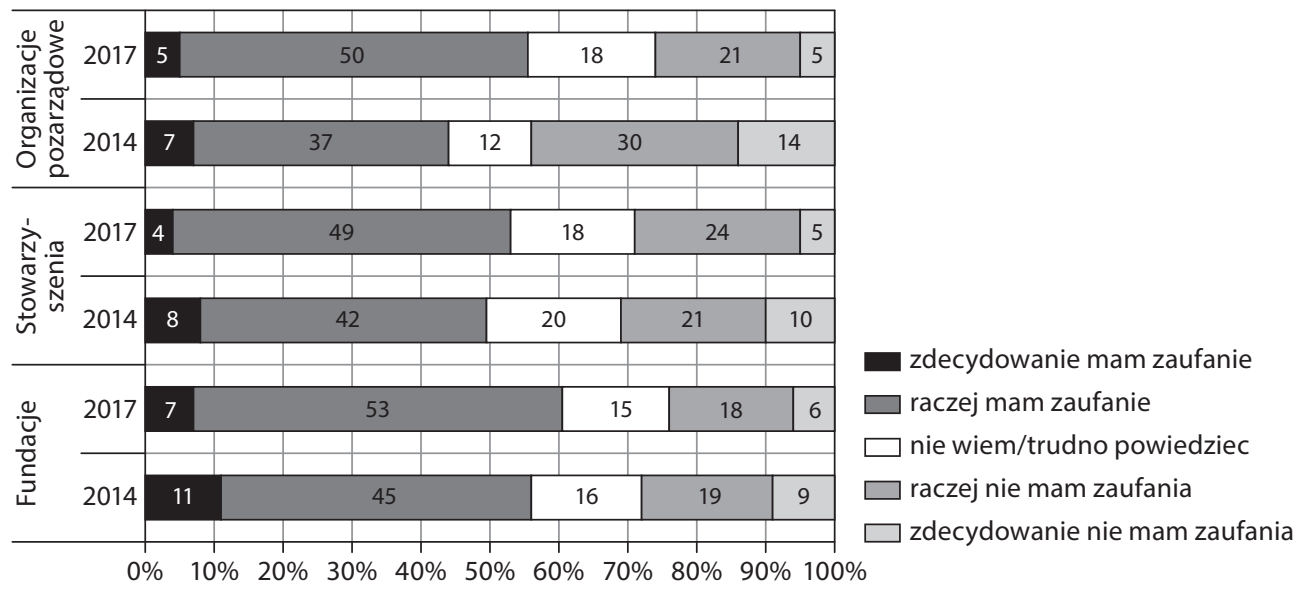

Źródło: [Gumkowska, 2017a].

może być zdiagnozowany dzięki wynikom badań zrealizowanych m.in. przez Stowarzyszenie Klon/Jawor 5 . W kolejnej części zostaną zaprezentowane najważniejsze wyniki dotychczas prowadzonych analiz.

Jednym z czynników ujawniających nastawienie, za pomocą którego w pośredni sposób można dokonać oceny wizerunku, jest zaufanie. Wyniki sondaży przeprowadzonych w 2014 i 2017 r. ukazują wzrost odsetka osób, które ufają (na podstawie odpowiedzi 'zdecydowanie mam zaufanie' i 'mam zaufanie') zarówno organizacjom pozarządowym, jak fundacjom i stowarzyszeniom. W 2017 r. największym zaufaniem cieszyły się fundacje (60\%), organizacjom pozarządowym ufało $55 \%$ badanych, a stowarzyszeniom - 53\% [Gumkowska, 2017a]. Jednocześnie zmniejszył się odsetek osób, które zadeklarowały zdecydowany brak zaufania do NGO. Szczegółowe wyniki z tego badania zostały zaprezentowane na rysunku 1.

Pierwszym skojarzeniem Polaków związanym z terminem organizacja pozarządowa jest pomaganie innym. Takie wyniki uzyskano

Zaprezentowano wyniki badania zrealizowanego na zlecenie Stowarzyszenia Klon/Jawor na reprezentatywnej próbie 1000 dorosłych Polaków przez firmę Realizacja sp. z o.o. w styczniu 2017 r. Źródło: publicystyka.ngo.pl zarówno w 2014 r. (40\% wskazań), jak i 2017 r. (37\% wskazań) [Gumkowska, 2017a; Gumkowska, 2017b]. Do innych ujawnianych przez badanych asocjacji należały: niesienie pomocy ludziom, niezależność w działaniu (niezależność od polityki, rządu), zbieranie pieniędzy czy po prostu konkretne formy prawne organizacji, w tym najczęściej fundacja. Należy zaznaczyć, iż w 2017 r. dla 27\% Polaków termin organizacja pozarzq̨dowa nie kojarzył się z niczym (w 2014 r. 40\% osób wyrażało taką opinię) [ibidem].

Badani identyfikują pomaganie ludziom jako główny obszar działalności organizacji pozarządowych, stwierdzając w tym, że są one skuteczniejsze w działaniu niż instytucje państwowe (58\% wskazań), ale prawie połowa respondentów (45\% wskazań) uważa, że podmioty trzeciego sektora marnują część pieniędzy, które otrzymują [Gumkowska, 2017b]. Dodatkowo należy podkreślić, iż badani deklarujący osobisty kontakt z organizacjami w przeciągu ostatniego roku przed realizacją badania mają na ogół o nich lepsze zdanie i postrzegają je jako bardziej innowacyjne, skuteczne, otwarte i niezależne. W tym kontekście systematyczne informowanie o podejmowanych inicjatywach wydaje się być niezbędnym kro- 
kiem dla uwiarygodnienia prowadzonych działań, który może pomóc w uzyskaniu poparcia dla prowadzonych aktywności.

Na podstawie wyników zrealizowanego przez Stowarzyszenie Klon/Jawor badania wśród liderów organizacji pozarządowych zostało określone, że wiele z nich nie prowadzi działań związanych z promocją czy kreowaniem wizerunku, ponieważ nie widzą takiej potrzeby. Wśród wymienianych przyczyn braku aktywności promocyjnej czy PR-owej wymieniają oni brak funduszy i większe znaczenie prowadzenia bieżących działań [Adamiak, 2015]. Przeprowadzone analizy wskazują, iż jedynie połowa organizacji publikuje informacje o swojej działalności na stronach internetowych, a jedynie jedna czwarta administruje profilem w mediach społecznościowych [ibidem].

Zaprezentowane wyniki dotychczasowych badań jednoznacznie wskazują na potrzebę systematycznych i planowych działań w zakresie kształtowania wizerunku. Szczególnie istotne wydaje się być wdrażanie narzędzi komunikacji z mediami, ponieważ 40\% Polaków o działaniach organizacji trzeciego sektora dowiaduje się za pośrednictwem mass mediów [Gumkowska, 2017b]. Z tej perspektywy brak aktywności w mass mediach oraz brak informacji o prowadzonych działaniach, czy też nie odnoszenie się do pojawiających się fake newsów czy (nie zawsze przychylnych) informacji o liderach organizacji mogą stać się czynnikami decydującymi o postrzeganiu danych organizacji. Sami badani również formułowali pogląd, iż organizacje pozarządowe powinny komunikować poprzez media o swoich działaniach (77\% respondentów udzieliło takiej odpowiedzi w badaniu zrealizowanym w 2014 r.).

Pomimo faktu, iż organizacje pozarządowe nie są podmiotami nastawionymi w swojej działalności na zysk, to analogicznie do innych przedsiębiorstw oferują na rynku produkty czy usługi. Można zaryzykować stwierdzenie, że podobnie jak w przypadku przedsiębiorstw działających w drugim sektorze, te z NGO, które chcą zbudować rozpoznawalną i godną zaufania markę oraz pozostać na rynku, powinny opracowywać i wdrażać strategie marketingowe. W najprostszy sposób strategie te można opisać za pomocą komponentów tworzących marketing-mix, czyli czterech głównych obszarów obecności przedsiębiorstwa na rynku (wśród których wyróżnia się: produkt, cenę, dystrybucję i promocję). W kształtowaniu wizerunku szczególnie przydatne mogą stać się narzędzia promocji, w tym szczególnie public relations. W kolejnych częściach artykułu zostanie zdefiniowane pojęcie wizerunku, a następnie zostaną opisane narzędzia PR, które mogą być wykorzystywane w jego kształtowaniu.

\section{Komponenty wizerunku}

Wizerunek jest definiowany jako wyobrażenie, jakie jedna lub wiele publiczności ma o osobie, przedsiębiorstwie lub instytucji [Wojcik, 2001]. Ten obraz nie jest czymś rzeczywistym, dokładnie i szczegółowo nakreślonym, ale jest mozaiką wielu szczegółów, podchwyconych fragmentarycznie i o nieostrych różnicach [Newsom, Scott, Vanslyke, 1989, s. 364]. Wizerunek może być traktowany jako synteza dotychczasowych doświadczeń, odczuć i przekonań, które powstają w wyniku porównania danego przedmiotu/organizacji z organizacjami konkurencyjnymi [Altkorn, 2004, s. 15]. Współcześnie dla przedsiębiorstw wizerunek jest jednym z ważniejszych niematerialnych zasobów [Budzyński, 2002, s. 24]. Wizerunek organizacji może być traktowany jako [Szromnik, 2007, s. 133]:

- pewne wyobrażenie ukształtowane w umysłach ludzkich,

- obraz pojęciowy realnej organizacji, osoby, procesu,

- mentalne odbicie rzeczywistości w świadomości otoczenia,

- skojarzenie, jakie nasuwa się na myśl o instytucji,

- subiektywne odwzorowanie rzeczywistości w świadomości adresatów, 
- emocjonalny odbiór, bez zniekształcenia jego istoty.

Zarówno na kształtowanie się, jak i na zmianę wizerunku może wpłynąć $z$ jednej strony każda informacja o danej organizacji, z drugiej - wszystkie zmiany zachodzące po stronie otoczenia. Stąd należy stwierdzić, że nie istnieje jeden stały wizerunek, a kilka podstawowych kategorii wizerunku, do których należą [Rozwadowska, 2002, s. 58]:

- wizerunek rzeczywisty - definiowany jako sposób postrzegania organizacji,

- wizerunek lustrzany - definiowany jako postrzeganie organizacji przez jej pracowników,

- wizerunek pożądany - inaczej wizerunek docelowy, który jest kształtowany przez organizację zgodnie z jej celami,

- wizerunek optymalny - inaczej wizerunek realny. Definiowany jest w kategoriach kompromisu między wyżej wymienionymi wizerunkami i odpowiada na pytanie: jaki realny wizerunek $w$ obecnej sytuacji można stworzyć.

Często występujący dysonans pomiędzy wizerunkami: rzeczywistym i pożądanym jest spowodowany przez nieskuteczną komunikację organizacji, rozbieżności między deklarowanymi a rzeczywistymi zachowaniami, złym dopasowaniem atrybutów tożsamości oraz zmianami otoczenia [Altkorn, 2004, s. 18].

Większe podmioty od lat starają się wykreować i wypozycjonować swoją własną markę (przykładami są tu np. Wielka Orkiestra Świątecznej Pomocy czy Rak'n'Roll). Wizerunek, obok świadomości istnienia danej organizacji, jest jednym z elementów składowych wiedzy o marce [Keller, 1998, s. 94]. Przy tym świadomość marki związana jest z jej rozpoznawalnością i możliwością przywoływania jej przez odbiorców. Z kolei wizerunek tworzą typy i siła skojarzeń z marką oraz przychylność i unikatowość tych skojarzeń.

Na wizerunek organizacji może wpłynąć wiele czynników, spośród których można wyodrębnić trzy podstawowe grupy: [Wojcik, 2001, s. 39-40]:

1) sprawy organizacji, które mogą być przedmiotem image'u, tworząc sub-wizerunki. Należą do nich: misja, wizja, normy postępowania, osobowość, tożsamość organizacji, a także oferta, programy i produkty;

2) komunikowanie o stanie spraw organizacji, w tym również $\mathrm{w}$ formie corporate identity;

3) społeczny rezonans grup, wśród których organizacja chce stworzyć określony wizerunek.

Odbiór podejmowanych przez organizacje działań zależy od wiedzy o organizacji, odczuć, oczekiwań, uprzedzeń oraz norm społecznych, z którymi dane grupy czują się związane. W praktyce organizacje, aby prowadzić skuteczną komunikację z otoczeniem, a poprzez nią kształtować swój wizerunek, mogą wykorzystywać różnorodne narzędzia marketingowe, w tym przede wszystkim techniki public relations.

\section{Public relations a kształtowanie wizerunku}

Jednym z podstawowych celów prowadzenia działań public relations w każdym przedsiębiorstwie jest nawiązywanie i podtrzymywanie wzajemnie korzystnych stosunków między instytucją a grupami publiczności, od których zależy jej sukces lub klęska [Cutlip, Center, Broom, 2000, s. 3]. Przy tym do podstawowych działań należą: kreowanie wizerunku, wyobrażenia o organizacji oraz jej reputacji. Planowanie działań public relations powinno obejmować cztery podstawowe fazy: badanie stanu wyjściowego, planowanie, realizację programów oraz kontrolę przebiegu realizacji i efektów [Wojcik, 2001, s. 281]. Badanie stanu wyjściowego wiąże się z poznaniem obrazu organizacji wśród członków zidentyfikowanego otoczenia wewnętrznego i zewnętrznego organizacji. W jej wyniku możliwe jest zdiagnozowanie przyczyn rozbieżności 
między wizerunkiem pożądanym a rzeczywistym, a na tej podstawie określenie celów, grup docelowych planowanych działań oraz wybór odpowiednich sposobów ich realizacji.

Dobór technik komunikacji powinien być poprzedzony analizą otoczenia i wyodrębnieniem grup docelowych, do których organizacje kierują swoje działania. Otoczenie każdej organizacji tworzone jest przez grupy, które wpływają na nią oraz takie, które są zainteresowane jej działalnością. W najprostszy sposób można je podzielić wyodrębniając te, które tworzą otoczenie wewnętrzne i zewnętrzne. Pomimo faktu, iż organizacje pozarządowe należą do jednego sektora, warto mieć na uwadze, że otoczenie poszczególnych podmiotów mogą tworzyć rozmaite grupy, związane ze specyfiką działania poszczególnych podmiotów. W przypadku NGO wewnętrzne otoczenie mogą stanowić na przykład: pracownicy, wolontariusze, zarząd oraz stali podopieczni. Wśród otoczenia zewnętrznego wyróżnić można: przedstawicieli urzędów i administracji, władze samo- rządowe, polityków, przedstawicieli mediów, sponsorów i darczyńców, beneficjentów, inne organizacje pozarządowe, firmy komercyjne oraz postronnych obserwatorów, którzy nie należą do wyżej wymienionych grup [Kotnis-Górka, Wysocki, 2011, s. 83]. Liczba i różnorodność poszczególnych grup tworzących otoczenie powoduje formułowanie wielu (czasem sprzecznych) oczekiwań wobec organizacji. Dlatego też ważne jest wykorzystywanie przy budowaniu wizerunku narzędzi dostosowanych do potrzeb każdej z nich.

Głównym celem oddziaływania na otoczenie wewnętrzne jest zbudowanie lojalności oraz poczucia identyfikacji z organizacją. Literatura z zakresu public relations wskazuje na techniki, poprzez które można budować programy komunikacji wewnętrznej. W tabeli 1 zostały zaprezentowane najważniejsze z nich. Umożliwiają one komunikowanie o celach organizacji i jej działaniach, pozyskiwanie zrozumienia dla podejmowanych decyzji, a przez to wzbudzanie poczucia odpowiedzialności.

\section{Tabela 1. Wybrane techniki komunikacji z otoczeniem wewnętrznym}

\begin{tabular}{|l|l|l|l|}
\hline \multicolumn{1}{|c|}{ Techniki werbalne } & \multicolumn{1}{|c|}{ Techniki pisemne } & \multicolumn{1}{c|}{ Techniki wizualne } & \multicolumn{1}{|c|}{ Techniki multimedialne } \\
\hline $\begin{array}{l}\text { Spotkania bezpośrednie } \\
\text { z członkami organizacji }\end{array}$ & Gazetka firmowa & Biuletyny wideo & $\begin{array}{l}\text { Telekonferencje i wideokon- } \\
\text { ferencje }\end{array}$ \\
\hline Instruktaże zespołowe & Direct mail & Tablice ogłoszeń & Pokazy i prezentacje \\
\hline Narady & Raporty roczne dla personelu & Wystawy & Spotkania integracyjne \\
\hline Intranet & $\begin{array}{l}\text { Konkursy wniosków uspraw- } \\
\text { niających }\end{array}$ & & Wydarzenia specjalne \\
\hline
\end{tabular}

Źródło: Opracowanie własne na podstawie: [Szymańska, 2004].

Komunikacja z otoczeniem zewnętrznym ma dwa zasadnicze cele: informowanie o sprawach związanych z organizacją oraz pielęgnowanie dobrych stosunków. Do ważniejszych narzędzi oddziaływania na otoczenie zewnętrzne należą:

- konferencje prasowe i pozaprasowe,

- corporate design - system identyfikacji wizualnej, na który mogą składać się: sym- bol firmy (logo, logotyp), jej kolory firmowe, druki, identyfikatory, materiały reklamowe, wystrój budynków, informacja wizualna,

- plakaty,

- foldery lub broszury firmowe,

- organizowanie "drzwi otwartych",

- filmy promocyjne,

- publikowanie sprawozdań z działalności, 
- organizowanie wydarzeń specjalnych (spotkania jubileuszowe, imprezy firmowe),

- strona internetowa,

- prowadzenie kanałów społecznościowych.

Z uwagi na fakt, iż media są współcześnie jednym z głównych źródeł informacji, stąd na postrzeganie organizacji wpływ ma również wykorzystanie narzędzi służących do współpracy z nimi, takich jak: konferencje prasowe, informacje prasowe, newslettery i biuletyny, oświadczenia czy publikacje w magazynach branżowych.

Przedstawione narzędzia nie stanowią wyczerpującej listy, wskazują jedynie na mnogość instrumentów, za pomocą których możliwe jest skuteczne zarządzanie komunikacją wewnętrzną i zewnętrzną. W praktyce dobór technik zależy w dużej mierze od kreatywności osób zajmujących się public relations czy promocją, budżetu i profilu grup docelowych. Nie mniej, w warunkach konkurencyjnego rynku, organizacje, które chcą odnieść sukces, powinny posiadać tzw. pozytywną odmienność [Altkorn, 1999]. W praktyce oznacza to określoną, wyróżniającą je spośród konkurencji tożsamość.

\section{Podsumowanie}

Organizacje pozarządowe stają się swego rodzaju markami. Starają się pozyskiwać sponsorów, wolontariuszy i sympatyków. Dlatego coraz większego znaczenia nabiera potrzeba świadomego kształtowania i zarządzania ich wizerunkiem. We współczesnym świecie ini-

\section{Literatura}

Adamiak P. (2015). Wizerunek organizacji pozarząowych. Raport z badania. Warszawa: Stowarzyszenie Klon/Jawor.

Altkorn J. (1999). „Tożsamość firmy. Pojęcia, funkcje, wdrażanie", Firma i rynek, nr 13.

Altkorn J. (2004). Wizerunek firmy. Dąbrowa Górnicza: WSB w Dąbrowie Górniczej.

Bogacz-Wojtanowska E. (2016) "Istota i podstawowe zasady funkcjonowania organizacji pozarządowych", w: E. Bogacz-Wojtanowicz, S. Wrona (red.), cjatywy obywatelskie stanowią ważny czynnik rozwoju demokratycznych społeczeństw. Dodatkowo należy zaznaczyć, iż aktywność społeczna Polaków jest w dużej mierze związana z ich opiniami na temat organizacji pozarządowych [Adamiak, 2015]. Wykorzystywanie narzędzi public relations, z których w codziennej działalności korzystają przedsiębiorstwa działające w drugim sektorze, mogłoby przyczynić się nie tylko do poprawy wizerunku NGO, ale również ułatwić im osiąganie założonych celów. Należy podkreślić, że w artykule zostały jedynie przedstawione podstawowe techniki PR, dzięki którym jest możliwe kształtowanie image'u i kontaktów z otoczeniem. Tym samym warte odrębnego opracowania byłoby przeprowadzenie analiz związanych z dotychczasowymi aktywnościami NGO w tym obszarze.

Niemniej wyniki dotychczasowych badań wskazują, iż potrzebne są działania, które kształtowałyby wizerunek zarówno trzeciego sektora jako całości, jak i poszczególnych organizacji działających w jego ramach. Ich celem powinno być systematyczne i świadome budowanie wizerunku poprzez komunikację. Z tej perspektywy staje się jasne, że samo posiadanie strony internetowej nie jest wystarczającym narzędziem oddziaływania na otoczenie. Planowe wdrażanie technik wypracowanych na gruncie public relations może pozwolić na bardziej efektywną komunikację, co w konsekwencji może prowadzić do wzrostu zaufania i poprawy wizerunku trzeciego sektora.

Zarzadzanie organizacjami pozarządowymi. Kraków: Instytut Spraw Publicznych Uniwersytetu Jagiellońskiego.

Budzyński W. (2002). Wizerunek firmy. Warszawa: Poltext.

Brzuska E., Kuklak-Dolata I., Nyk M. (red.) (2017). Ekonomia społeczna. Teoria i praktyka przedsiębiorczości społecznej. Warszawa: Difin.

Cutlip S.M., Center A.H, Broom G.M. (2000). Effective Public Relations. New York: Prentice Hall. 
Czapiński J., Panek T. (red.) (2015). Diagnoza spoteczna 2015. Warunki i jakość życia Polaków. Warszawa: Vizja Press\&IT.

Gliński P. (2006). Style działań organizacji pozarządowych w Polsce. Grupy interesu czy pożytku publicznego. Warszawa: Wydawnictwo IFiS PAN.

Gumkowska M. (2017a). Im bardziej nas znaja tym bardziej nam ufaja, https://publicystyka.ngo.pl/im-bardziej-nas-znaja-tym-bardziej-nam-ufaja (dostęp: 13.12.2018).

Gumkowska M. (2017b). Co o organizacjach myśla Polacy. Cz. 1, https://publicystyka.ngo.pl/co-o-organizacjach-mysla-polacy-cz-1 (dostęp: 13.12.2018).

Hebrig P., Milewicz J. (1995). „To be or not to be: credible that is: A Model of credibility among competing firms", Marketing intelligence and planning, nr 13(6).

Keller K.L. (1998). Strategic Brand Management Building, Measuring and Managing Brand Equity. New Jersey: Prentice Hall.
Kotnis-Górka E., Wysocki M. (2011). Organizacje pozarządowe. Zarzadzanie, kreowanie wizerunku i współpraca z mediami w III sektorze. Gliwice: Helion.

Newsom D., Scott A., Vanslyke T.J. (1989). This is Public Relations. The Realities of Public Relations. Belmont: Wadsworth.

Rozwadowska B. (2002). Public relations - teoria, praktyka, perspektywy. Warszawa: Studio Emka.

Szromnik A. (2007). Marketing terytorialny. Miasto i region na rynku. Kraków: Wolters Kluwer.

Szymańska A. (2004). Public relations w systemie zintegrowanej komunikacji marketingowej. Wrocław: Oficyna Wydawnicza UNIMEX.

Ustawa z dnia 24 kwietnia 2003 r. o działalności pożytku publicznego i o wolontariacie, Dz.U. 2018 poz. 450, z późn. zm.

Wojcik K. (2001). Public relations od A do Z. Analiza sytuacji wyjściowej. Planowanie działalności. Warszawa: Agencja wydawnicza Placet.

\section{Image building for non-governmental organizations}

Summary: Image is one of the most important intangible organizational resources. Non-governmental organizations competing for volunteers, sponsors or supporters. Increasing competition enforces professionalization of management's as well as marketing activities supporting image creation. The aim of this article is to present public relations tools and techniques that can be used to maintain or build relations with specific target publics and to create positive image. The study presents the basic components of the image, public relations techniques used in communication with the internal and external environment as well as the results of the current third sector image research. The study shows that non-governmental organizations need to build and solidify their brand image.

Keywords: image, image building, non-governmental organizations.

\section{Prawa autorskie i licencja / Copyright and License}

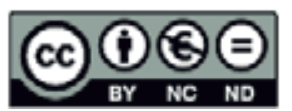

Artykuł opublikowano na licencji Creative Commons Uznanie autorstwa - Użycie niekomercyjne - Bez utworów zależnych 3.0 Polska http://creativecommons.org/licenses/by-nc-nd/3.0/pl/

This article is published under the terms of the Creative Commons Attribution - NonCommercial - NoDerivs (CC BY-NGND 3.0) License http://creativecommons.org/licenses/by-nc-nd/3.0/ 